\title{
CARACTERIZAÇÃo MOLECULAR DE CULTIVARES DE PESSEGUEIRO E NECTARINEIRA COM MICROSSATÉLITES ${ }^{1}$
}

\author{
VALMOR JOÃO BIANCHI ${ }^{2}$, JOSÉ CARLOS FACHINELLO ${ }^{3}$, MÁRCIA WULFF SCHUCH ${ }^{3}$, SILVIERO SANSAVINI $^{4}$
}

\begin{abstract}
RESUMO - Na certificação de mudas de plantas frutíferas, a identificação genética é importante em todas as etapas do processo de produção. Em pessegueiro, a identificação de genótipos baseada somente em características morfofenológicas deixa dúvidas quanto à verdadeira identidade de algumas cultivares. Marcadores moleculares de microssatélies foram utilizados objetivando a caracterização molecular de 8 cultivares de nectarineira e 28 de pessegueiro. Para a análise, foram utilizados 13 incializadores de microssatélites (primers), sendo que todos foram marcadores produzindo polimorfismo suficiente para identificar 32 das 36 cultivares analisadas. A maior similaridade genética verificada nas cultivares para consumo in natura foi entre Coral e Planalto $(0,94)$ e entre Della Nona e Marfim $(0,90)$, enquanto, para os pessegueiros para indústria, foi de 0,93 entre Jubileu e Capdeboscq e de 0,92 entre Jade e Esmeralda. Os marcadores de microssatélites permitiram separar em grupos distintos as nectarineiras e os pessegueiros de consumo in natura dos de indústria, havendo uma elevada concordância entre os dados genealógicos das cultivares e os dados gerados pelos microssatélites, confirmando a grande utilidade da técnica para a caracterização genética.
\end{abstract}

Termos para indexação: Pruus persica, simples seqüências repetidas, fingerprinting.

\section{MOLECULAR CHARACTERIZATION OF PEACH AND NECTARINE CULTIVARS THROUGH MICROSATELLITES MARKERS}

\begin{abstract}
Genetic identification of fruit tree plants is important in all phases of the production process. On peach the genotypes identification based only on the morphologic and phenologic characteristics leaves doubts on the true identity of some cultivars. Microsatellite markers were used aiming at the molecular characterization of eight nectarine and 28 peach cultivars. Thirteen microsatellite primers were used and all of them generated enough polimorfism that may identify 32 out of 36 of the analysed cultivars. The greatest genetic similarity was found between the fresh market 'Coral' and 'Planalto' $(0,94)$ and between the 'Della Nona' and 'Marfim' cultivars $(0,90)$, whereas for caning peaches the similarity was 0,93 between the 'Jubileu' and 'Capdeboscq' cultivars and 0,92 between the 'Jade' and 'Esmeralda' ones. The microsatellite markers made possible to separate into distinct groups of the nectarines and fresh market peaches from those caning cultivars that showed a high agreement among genealogical data and those of microsatellite markers that confirm tha this technique is useful for genetic characterization.
\end{abstract}

Index terms: Prunus persica, single sequence repeat, fingerprinting.

\section{INTRODUÇÃO}

Até meados da década de 60, a diferenciação de genótipos nos estudos de genética e melhoramento estava associada às características morfofenológicas das plantas. Porém, este método de análise tem como limitações as influências ambientais sobre o fenótipo, além do gasto excessivo de tempo e dinheiro (Sansavini, 1998). Dentro do gênero Prunus, o pessegueiro e a nectarineira pertencem à espécie de menor variabilidade genética, possuindo baixo polimorfismo das características morfofenológicas (Vinatzer et al., 1999) de tal maneira que, muitas vezes, a identificação entre cultivares baseada somente no fenótipo deixa muitas dúvidas quanto à verdadeira identidade dos genótipos (Pancaldi et al., 1999). Buscando superar este fator limitante, novos métodos de análise foram sendo introduzidos em auxílio à caracterização genética de cultivares. Inicialmente, a análise isoenzimática tem sido empregada para identificação de cultivares (Pancaldi \& Battistini, 1991); entretanto, esta técnica não fornece polimorfismo suficiente para uma caracterização detalhada de genótipos de baixa variabilidade, como é o caso do pessegueiro, não permitindo a individualização, mas somente a separação em grupos (Arulsekar \& Parfitt, 1986; Lima, 2001). Porém, quando se utilizam marcadores moleculares, a possibilidade de identificação de genótipos aumenta consideravelmente em todas as espécies frutícolas (Mulcahy et al., 1993), nas quais a combinação de poucos marcadores são suficientes para diferenciá-las, produzindo um tipo de impressão digital molecular da planta, também conhecida como fingenprinting varietal, a qual é obtida a partir da análise do DNA das mesmas (Sansavini, 1998).

Entre os marcadores moleculares disponíveis atualmente para análise genética, os microssatélites ou SSR representam regiões de DNA de sequiência repetida em número variável. Os microssatélites apresentam como vantagens o carácter co-dominante, elevado polimorfismo e alta reprodutibilidade, características importantes para análise baseada em marcadores moleculares (Sansavini, 1998; Sosinski et al., 2000).

Garantias de idoneidade genética do material vegetal é um atributo qualitativo de grande importância para o setor viveirístico e frutícola, para a formação de pomares de qualidade. Portanto, o objetivo deste trabalho foi verificar a viabilidade de utilização dos marcadores microssatélites na caracterização de um grupo de cultivares de pessegueiro e de nectarineira de importância econômica no Brasil.

\section{MATERIALEMÉTODOS}

No presente estudo, foram analisados 36 genótipos de Prunus persica, sendo 8 cultivares de nectarineira, 14 cultivares de pessegueiro para consumo in natura, 4 de dupla finalidade e 10 do tipo indústria (Tabela 1). As análises moleculares foram realizadas nos Laboratórios de Biologia Molecular, da Universitá Degli Studi di Bologna - Itália, e no de Cultura de Tecidos Vegetais, do Departamento de Botânica da Universidade Federal de Pelotas, Pelotas-RS. As análises foram repetidas em ambos os laboratórios a partir de DNA extraído de folhas coletadas de duas plantas diferentes.

O material vegetal utilizado nas análises foi obtido na Embrapa Clima Temperado, Pelotas-RS e no Viveiro Quinta Marli, Pelotas-RS. Para as análises, a extração do DNA foi realizada utilizando amostras com $50 \mathrm{mg}$ de folhas liofilizadas, conforme metodologia descrita por Mulcahy et al. (1993) e com modificações conforme Bianchi et al. (2002); o DNA obtido foi diluído em TE pH 8,0 e, após tratamento com RNAse, foi quantificado com fluorímetro (Hoefer Instrument, TK100 Model) e diluído com água estéril para a concentração final de $20 \mathrm{ng} . \mu \mathrm{L}^{-1}$, para ser utilizado na Reação da Polimerização em Cadeia (PCR).

\footnotetext{
${ }^{1}$ (Trabalho 012/2004). Recebido: 28/01/2004. Aceito para publicação: 13/08/2004. Trabalho desenvolvido com apoio financeiro do CNPq, CAPES e Fapergs.

${ }^{2}$ Eng $^{\circ}$ Agr $^{\circ}$, Dr., Bolsista Prodoc/CAPES, Departamento de Fitotecnia, Área de Fruticultura de Clima Temperado, FAEM/UFPel, C.P. 354, 96010-900, Pelotas-RS. Fone: (53) 2757124 - E-mail: valmorjb @ yahoo.com.

${ }^{3}$ Eng $^{\circ}$ Agr $^{\circ}$, Dr., Prof. de Fruticultura, FAEM/UFPel, C.P 354, 96010-900, Pelotas-RS.

${ }^{4}$ Prof. Fruticultura, Dipartimento di Colture Arboree - Università Degli Studi di Bologna, Bologna, Italia.
} 
TABELA 1 - Cultivares de pessegueiro e de nectarineira analisadas com marcadores microssatélites e respectivos dados de genealogia, Pelotas-RS, 2002.

\begin{tabular}{|c|c|}
\hline Cultivares & Dados genealógicos \\
\hline & Nectarineiras \\
\hline 01 - Sunred & Fla R9T10 x Panamint $\{$ (Gold Mine x Rio Oso Gem) x (Babcok x Boston $)\}$ \\
\hline $02-$ Mara & Nectared 9 x Sunred \\
\hline 03 - Armking & Palomar x Springtime \{(Luken’s Honey x Juli Elberta) x Robin $\}$ \\
\hline $04-$ Sungold & NJ 5107397 x Okinawa \\
\hline 05 - Sunlite & Fla.8B-27 (Okinwa x Panamint) $x$ NJN21 \\
\hline 06 - Anita & 77.2163 (Introdução de New Jersey) \\
\hline 07 - Dulce & 77.2162 (Introdução de New Jersey) \\
\hline 08 - Bruna & Introdução Americana \\
\hline & Pessegueiros para consumo in natura \\
\hline 09 - Pampeano & Não disponível \\
\hline 10 - Coral & $\{$ Delicioso (Introdução 619 - E.E. Pomicultura Taquari) $\}$ x $\{$ Interlúdio (Jewel x Southland) PL $\}$ \\
\hline 11 - Marli & Delicioso x Prelúdio \\
\hline 12 - Chiripá & Delicioso x Nectared 5 \\
\hline 13 - Della Nona & $\{$ Delicioso $\} \times$ x $\{$ Nectared 5 (Introdução 763 - New Jersey - EUA) $\}$ PL \\
\hline 14 - Chimarrita & Babcock x Flordabella \\
\hline 15 - Planalto & Coral x Babcok (Introdução - E. E. São Pedro-Argentina) \\
\hline 16 - Pialo & Vespertino PL \\
\hline 17 - Chirua & $\{$ BR-1 (Delicioso x Panamint) $\} \times\{$ Cascata 277 (Princesa $\times$ Colibri) $\}$ \\
\hline 18 - Vila Nova & Cristal x Princesa \\
\hline 19 - Saco de Touro & Não disponível \\
\hline 20 - Premier & (Cardeal x 15 de Novembro) PL \\
\hline 21 - Charme & Cascata $340 \times$ BR1 \\
\hline 22 - Marfim & Coral x Gang Shan Shang \\
\hline & Pessegueiros dupla finalidade \\
\hline 23 - Riograndense & Brilhante x NJC 97 (EUA) \\
\hline 24 - Leonense & F2 Brilhante x NJC 97 (EUA) \\
\hline 25 - Eldorado & $\{$ Gaudério (Delicioso x Interlúdio) PL $\}$ x $\{$ Serrano (City Row 29) PL $\}$ \\
\hline $26-$ Maciel & $\{$ Conserva 171 (Aldrighi - Seleção $493 \times$ Pelotas 76$)\} \times\{$ Conserva $334($ selec de sementes dos EUA $)\}$ \\
\hline & Pessegueiros tipo indústria \\
\hline 27 - Jubileu & Bolinha x Conserva 662 \\
\hline 28 - Pepita & Precocinho PL \{Capdeboscq (Lake City x Intermediário) PL x $\{$ Madrugador (Aldrighi x Taquari Precoce PL) $\}$ \\
\hline 29 - Adrighi & Seleção 439 (Pelotas-RS) PL \\
\hline 30 - Diamante & \{Convênio\} x \{Pelotas 77 (Aldrighi - Seleção 439 x Cardeal - I-57-100-3)\} \\
\hline $31-$ Precocinho & Diamante PL \\
\hline 32 - Esmeralda & \{Alpes (Aldrighi - Seleção 439 x Tapes) $\} \times\{$ RR $37-201$ (EUA) $\}$ \\
\hline 33 - Jade & $\{$ Alpes (Aldrighi - Seleção 439 x Tapes) $\}$ x $\{$ RR 53-272 (EUA) $\}$ \\
\hline $34-$ Capdeboscq & $\begin{array}{l}\text { \{Lake City (Introdução } 625 \text { - E.E. Pomicultura Taquari)\} x \{Intermediário (S -56-37 seleção da Colônia de } \\
\text { Pelotas)\} PL }\end{array}$ \\
\hline 35 - Granada & $\{$ Alpes (Aldrighi - Seleção 439 x Tapes) $\}$ x \{Conserva $102-\mathbf{I}-67-5-56\}$ \\
\hline 36 - Magno & Ambrosio Perret x Tapes \\
\hline
\end{tabular}

PL: Polinização livre

Fonte: Arquivos da Embrapa Clima Temperado, Pelotas-RS (2002).

Os primers microssatélites utilizados foram o UDP96-001, UDP96-003, UDP96-005, UDP96-008, UDP96-013, UDP96-018, UDP96019, UDP97-402, UDP98-022, UDP98-024, UDP98-407, UDP98-412 e UDP98-414, cujas sequiências são descritas por Cipriani et al. (1999). As reações de PCR foram conduzidas em aparelho termociclador "MJ PTC100 " em volume de $25 \mu \mathrm{L}$ contendo 10 mmol. $\mathrm{L}^{-1}$ Tris- $\mathrm{HCl} \mathrm{pH}$ 9,0; 50 mmol. $\mathrm{L}^{-1} \mathrm{KCl}, 1,5$ mmol.L $\mathrm{L}^{-1} \mathrm{MgCl}_{2} ; 0,2$ mmol.L $\mathrm{L}^{-1}$ de cada dNTP; 0,2 mmol.L ${ }^{1}$ de cada primer; 0,1 Unidades de Taq polimerase (Amersham Pharmacia Biotech); 50 ng de DNA genômico e, ao final, adicionou-se uma gota de óleo mineral. O perfil térmico utilizado foi um ciclo a $95^{\circ} \mathrm{C}$ por $5 \mathrm{~min}, 35$ ciclos a $94^{\circ} \mathrm{C}$ por $45 \mathrm{~s} ; 57^{\circ} \mathrm{C}$ por $45 \mathrm{~s} \mathrm{e} 72^{\circ} \mathrm{C}$ por $45 \mathrm{~s}$, seguindo-se de um ciclo final a $72^{\circ} \mathrm{C}$ por $8 \mathrm{~min}$.

Aos produtos da reação de PCR foram adicionados $10 \mu \mathrm{L}$ de solução desnaturante ( $98 \%$ formamida, 10 mmol.L ${ }^{-1}$ EDTA, $0,05 \%$ azul de bromofenol e $0,05 \%$ xyleno cyanol), seguido de tratamento térmico a $95^{\circ} \mathrm{C}$ por 5 minutos. Uma aliquota de $4,5 \mu \mathrm{L}$ de cada amostra amplificada foi aplicada ao gel. A eletroforese foi conduzida em gel de poliacrilamida a $6 \%$, em tampão 1 X TBE a 7 V.cm $\mathrm{cm}^{-1}$, pelo período de 2 horas e 30 minutos. A coloração do gel foi realizada utilizando nitrato de prata, segundo a metodologia descrita no Manual Promega "Silver Sequencing” (Promega, Madison, Wisconsin, USA).

Os produtos da amplificação visualizados no gel, produzidos por cada primer, foram utilizados na elaboração de uma matriz de similaridade genética, por meio do registro da presença (1) e da ausência (0) de bandas no perfil eletroforético de cada genótipo, e serviu para a diferenciação das cultivares. A similaridade genética foi calculada usandose o coeficiente de Dice e, para visualizar a forma de agrupamento das cultivares, foi elaborado o dendrograma empregando-se o método UPGMA (Unweighted pair group mean average), utilizando o software NTSYS.pc versão 2.1 (Rohlf, 2000).

\section{RESULTADOS E DISCUSSÃO}

O número de alelos amplificados com cada primer variou de três com UDP96-019, UDP97-402 e UDP98-022 até sete com UDP98-414, enquanto o número de bandas amplificadas variou de uma a três por genótipo (Figura 1A e 1B).

Os 13 primers utilizados amplificaram um total de 56 alelos, dos 


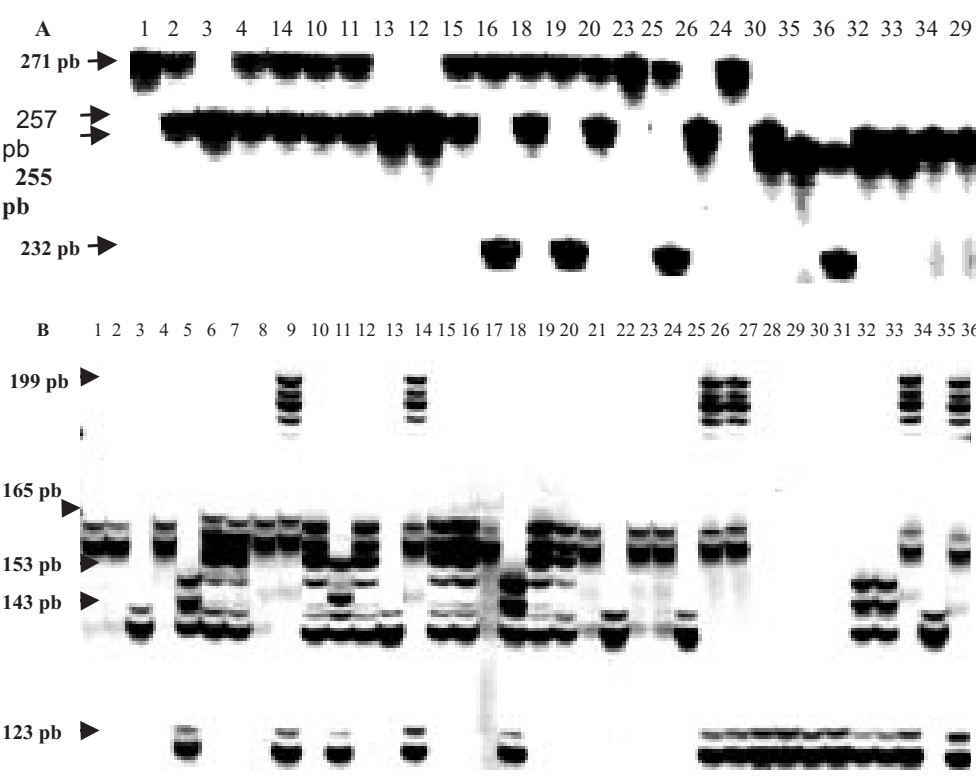

FIGURA 1 - Produtos da amplificação gerados pelos marcadores SSR UDP96-018 (A) e UDP96-008 (B) nas cultivares: 1-Sunred, 2-Mara, 3-Armking, 4-Sungold, 5-Sunlite, 6-Anita, 7-Dulce, 8-Bruna, 9-Pampeano, 10-Coral, 11-Marli, 12-Chiripá, 13Della Nona, 14-Chimarrita, 15-Planalto, 16-Pialo, 17-Chirua, 18- Vila Nova, 19-Saco de Touro, 20-Premier, 21-Charme, 22-Marfim, 23-Riograndense, 24-Leonense, 25-Eldorado, 26-Maciel, 27-Jubileu, 28-Pepita, 29-Aldrighi, 30-Diamante, 31-Precocinho, 32-Esmeralda, 33-Jade, 34-Capdeboscq, 35Granada e 36-Magno. À esquerda da figura está indicado o tamanho dos alelos. Pelotas-RS, 2002. quais 55 (98,2\%) foram polimórficos e permitiram a diferenciação de 32 genótipos dos 36 analisados. Somente UDP98-022 apresentou uma banda monomórfica para as cultivares testadas. Este resultado deve-se, principalmente, à presença de cultivares pertencentes ao grupo indústria, dupla finalidade e consumo in natura, o qual contribui para aumentar a proporção de alelos distintos.

Com a repetição das análises em dois laboratórios distintos, verificou-se que genótipos iguais, porém, de diferente procedência, apresentaram perfis eletroforéticos iguais, confirmando a confiabilidade da técnica, também verificada na análise genética de diferentes espécies do gênero Prunus (Pancaldi et al.,1999; Bianchi et al., 2002). Essa confiabilidade e o poder da técnica SSR foi também demonstrada por Sosinski et al. (2000) na diferenciação de pessegueiros da cv. Springcrest, nos quais os microssatélites detectaram variabilidade entre plantas da mesma cultivar, porém originadas de três fontes diferentes.

Das 8 nectarineiras analisadas, 4 ficaram no mesmo grupo da cultivar de pessegueiro Charme (Figura 2). As cultivares de nectarineira Armking e Sunlite, Anita e Dulce formaram dois grupos distintos, porém sempre relacionados com cultivares de pessegueiro para consumo in natura. A similaridade genética estimada para 'Dulce' e 'Anita' com os microssatélites foi de 0,82 (Figura 2), sendo maior do que aquela obtida por Lima (2001) através do polimorfismo do DNA amplificado ao acaso ou RAPD $(0,75)$. Para as cultivares Coral e Marfim, a similaridade estimada por RAPD foi de 0,87 (Lima, 2001), e de 0,85 com os microssatélites, revelando boa concordância entre os dados gerados por ambos os marcadores e os dados genealógicos destas cultivares (Tabela 1).

Dentre os pessegueiros para consumo in natura, os maiores valores de similaridade foram verificadas entre as cvs. Coral e Planalto $(0,94)$ e Della Nona e Marfim $(0,90)$ (Figura 2). Isto se deve à constituição genética das 4 cultivares, já que 'Coral' e 'Della Nona' possuem como

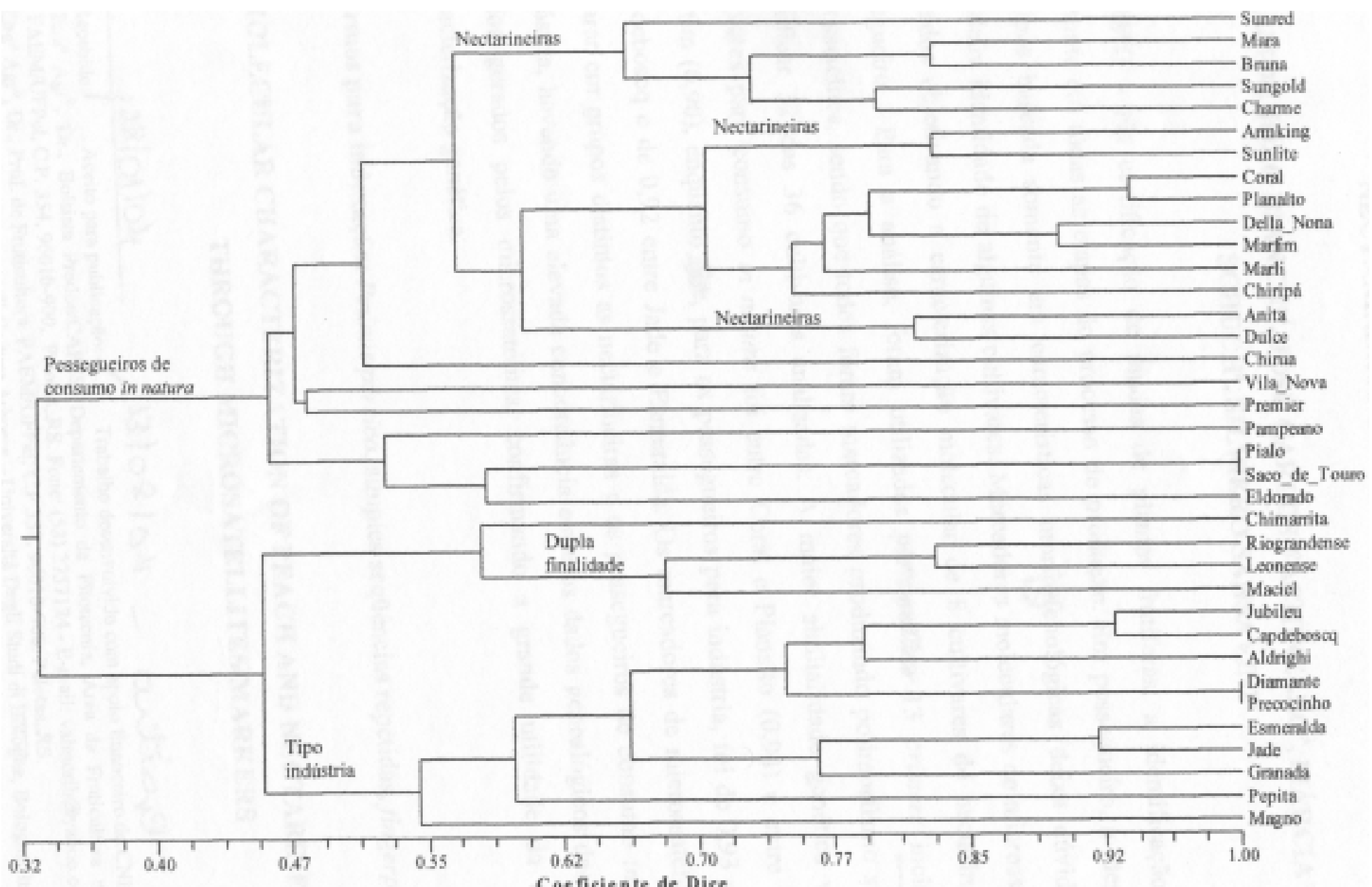

FIGURA 2 - Dendrograma baseado na análise de marcadores microssatélites em 36 cultivares de Prunus persica (L.) Batsch, calculado pelo método UPGMA. Pelotas-RS, 2002. 
ancestral comum a cv. Delicioso, enquanto 'Planalto'e 'Marfim' têm em comum a cv. Coral (Tabela 1). Esta mesma comparação pode ser feita entre as cvs. Marli e Chiripá, que possuem em comum a cv. Delicioso e estão agrupadas mais próximas de 'Marfim' e 'Della Nona', o que pode ser atribuído ao fato de 'Della Nona' e 'Chiripá' possuírem como genitor comum a cv. Nectared 5 (Tabela 1).

Obteve-se uma clara separação dos pessegueiros tipo indústria. Os de dupla finalidade formaram um grupo separado, porém mais próximo do tipo indústria, com exceção da cv. Eldorado (Figura 2). Neste caso, também se observa uma estreita relação entre os dados moleculares e os genealógicos (Tabela 1) de 'Riograndense' e 'Leonense' com similarididade estimada em 0,83 (Figura 2), ambos com origem das cvs. Brilhante e NJC97.

De acordo com os dados da Tabela 1, existe um estreito grau de parentesco entre as cultivares Precocinho e Diamante. Neste trabalho, não foi possível a diferenciação destas duas cultivares, possivelmente em função do número de primers e do alto grau de parentesco. A análise com um maior número de primers microssatélites, possivelmente, poderá diferenciar estas duas cultivares, pois, de acordo com análise RAPD realizada por LIMA (2001), foi possível diferenciar estes dois genótipos, confirmando que não se trata da mesma cultivar. Para 'Pialo' e 'Saco de Touro', a análise com 13 primers SSR produziram perfis eletroforéticos idênticos. Neste caso, análises com maior número de primers e uma nova avaliação das características morfofenológicas das plantas se fazem necessárias, além da utilização de outras técnicas moleculares como RAPD e polimorfismo no comprimento dos fragmentos amplificados ou AFLP, a fim de verificar se esse é um caso de sinonímia.

De modo geral, um grande número de polimorfismo foi gerado pelos marcadores microssatélites utilizados, principalmente por UDP98414, UDP96-005, UPD96-003. Verificou-se que a técnica apresenta vantagens quando comparada aos RAPD e isoenzimas, devido ao maior número de polimorfismo e repetibilidade dos resultados. Além disso, possui alta aplicabilidade entre espécies correlaciondas, conforme verificado por Pancaldi et al. (1999) e por Cipriani et al. (1999), em várias espécies de Prunus spp..

\section{CONCLUSÕES}

1) A técnica baseada em marcadores de microssatélites produz elevado polimorfismo entre cultivares de pessegueiro.

2) Marcadores de microssatélites podem ser utilizados na certificação da idoneidade genética de plantas de pessegueiro e nectarineira cultivadas no Brasil.

\section{REFERÊNCAS}

ARULSEKAR, S.; PARFITT, D.E. Isozymes analyses procedures for stone fruits, almond, grape, walnut, pistachio, and fig. HortScience, Alexandria, v.21, n.4, p.928-933, 1986.

BIANCHI, V.J.; VENTURI, S.; FACHINELLO, J.C.; TARTARINI, S.; SANSAVINI, S. I marcatori AFLPe SSR, risolutivi nella identificazione genetica delle varietà di susino. Frutticoltura, Bologna, n.4, p.8387, 2002.

CIPRIANI, G.; LOT, G.; HUANG, W.G.; MARRAZZO, M.T.; PETERLUNGER, E.; TESTOLIN, R. AC/GT and AG/CT micosatellite repeats in peach [Prunus persica (L.) Batsch]: isolation, characterization and cross-species aplication in Prunus. Theoretical and Applied Genetics, New York, n.99, p.65-72, 1999.

LIMA, M.R.M.S. Caracterização de cultivares de Prunus persica (L.) Batsch através de marcadores moleculares. 2001. 33f. Dissertação (Mestrado em Produção Vegetal) - Universidade Federal de Pelotas, Pelotas, 2001.

MULCAHY, D.L.; CRESTI, M.; SANSAVINI, S.; DOUGLAS, G.C.; LINSKENS, H.F.; BERGAMINI MULCAHY, G.; VIGNANI, R.; PANCALDI, M. The use of random amplified polymorphic DNAs to fingerprint apple genotypes. Scientia Horticulturae, Amsterdan, v.54, p.89-96, 1993.

PANCALDI, M.; BATISTTINI, S. Uttilizo degli isoenzime per l'identificazione varietale in albicocco. Atti Convegno AgroBioFrut, Cesena, p.195-202, 1991.

PANCALDI, M.; KAÇAR, T.; KUDEN, A.B.; SANSAVINI, S. Impiego di microsatelliti sequenziati nel pesco per il "fingerprinting" e l' analisi genealogica del mandorlo. Frutticoltura, Bologna, n.11, p.70-73, 1999.

ROHLF, F.J. NTSYS.PC. Numerical taxonomy and multivariate analysis system. Version 2.1. New York: Exeter Publications, 2000.

SANSAVINI, S. Biotecnologie frutticole: le nuove frontiere delle ricerche per il miglioramento genetico e la propagazione delle piante da frutto. Frutticoltura, Bologna, n.5, p.75-81, 1998.

SOSINSKI, B.; GANNAVARAPU, M.; HAGER, L.D. Characterization of microsatellite markers in peach [Prunus persica (L.) Batsch]. Theoretial and Applied Genetics, New York, n.101, p.421-428, 2000

VINATZER, B.; PANCALDI, M.; SANSAVINI, S. Potenzialità e limiti del "fingerprinting" nell'identificazione varietale del pesco. Frutticoltura, Bologna, n.4, p.97-101, 1999. 